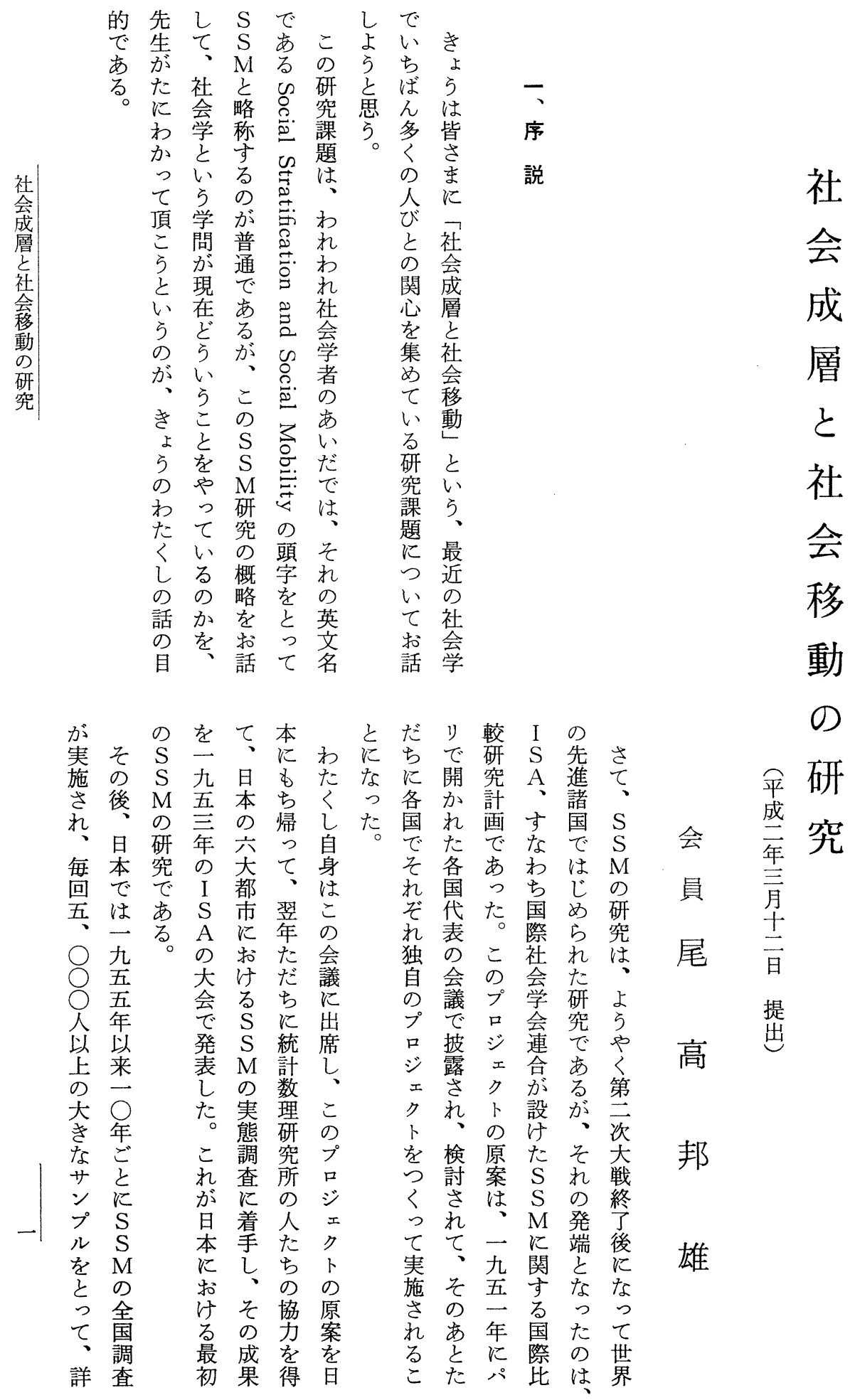




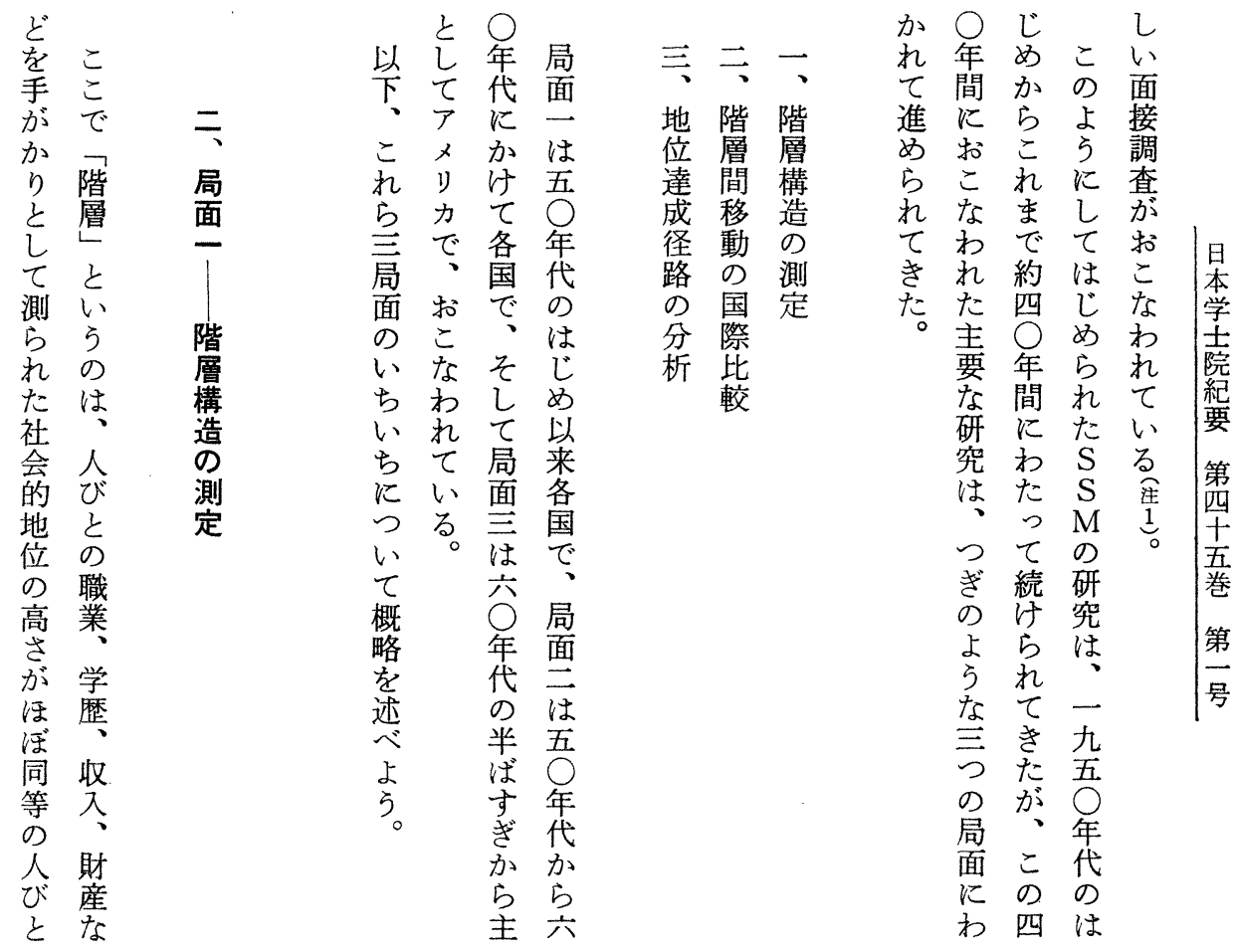

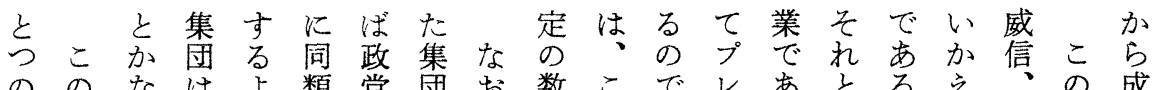

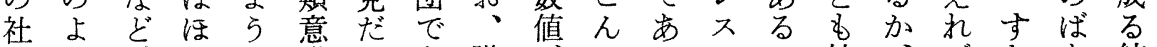

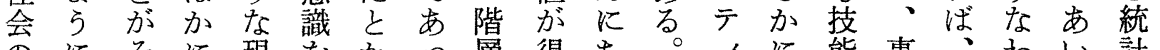

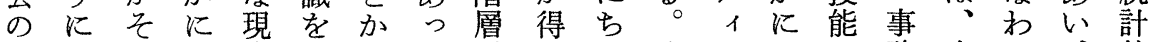

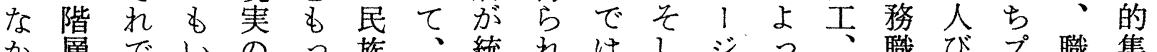

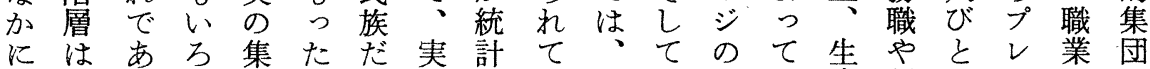
上統るい団りと在的い国、度異産販のスので 流計。ろで、かす集る勢こ合な王壳職テ市

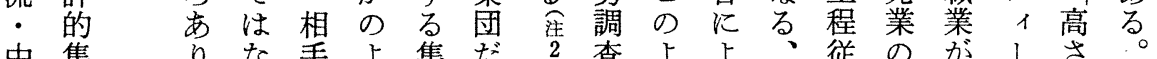

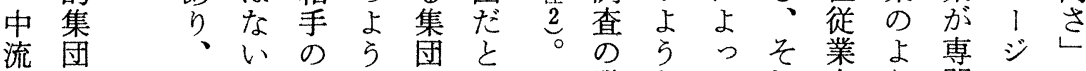

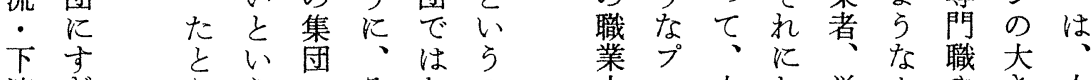

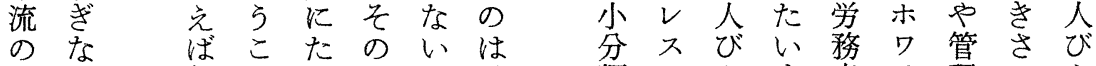
ら

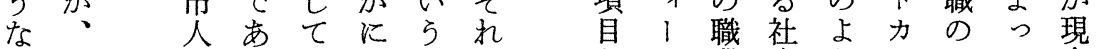

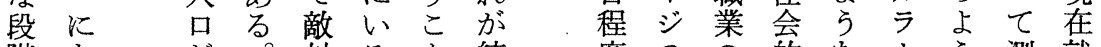

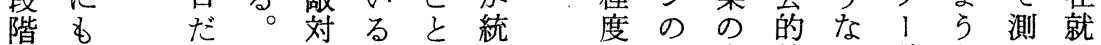
をかとこ意人で計市大高尊ブ職ならい 区かかの識たあ的故さ敬儿業工机て

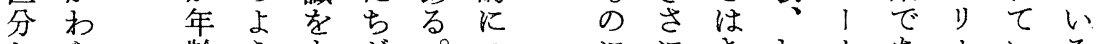

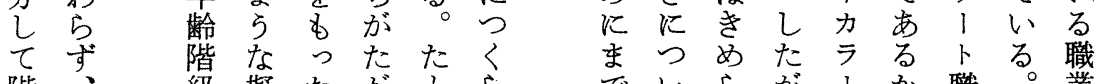

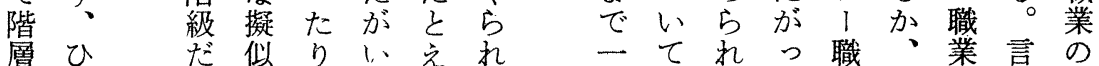




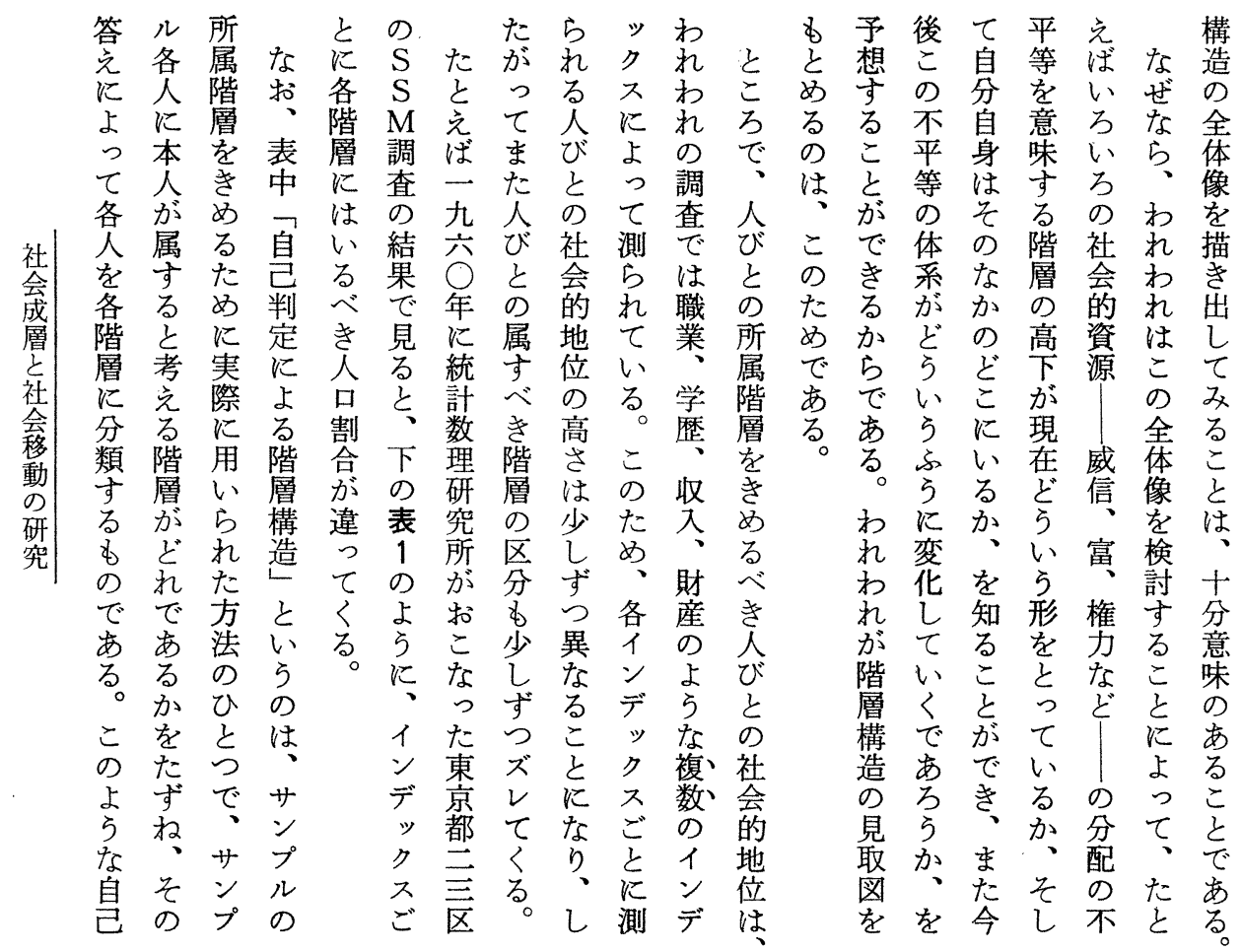

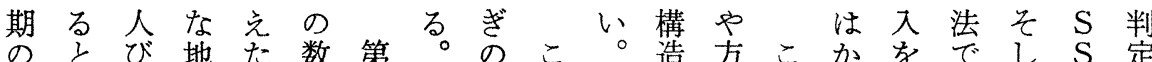

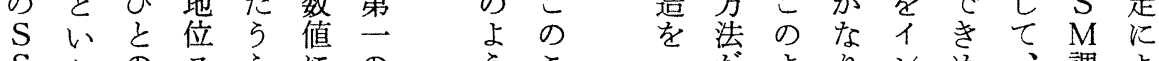

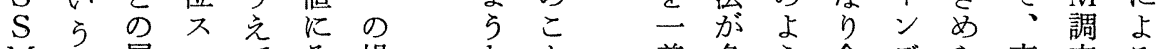
$\mathrm{M}$ 属 コ染操なと義多ら食デら表查る

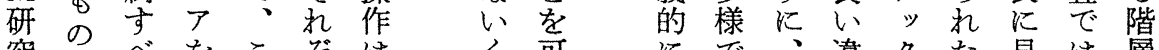
究でべをこ枈は可はで、違クた見は層 であ゙さう能測あ階っ不所らし決 はあ階くら妥既加定れ層てと属れば定

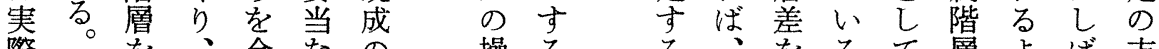
際こを、合なの操るるる、省るて層よば方 試の義れ䛉ウ、

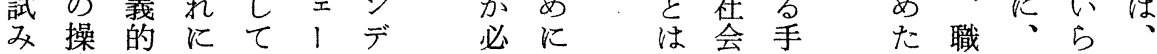

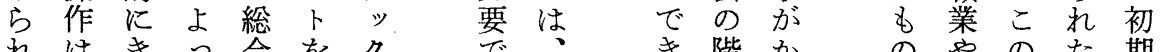

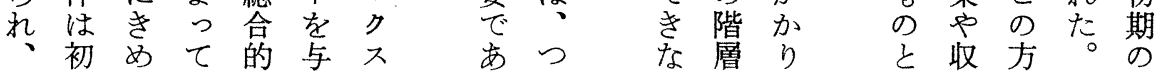

表 1：指標別階層構造の比較（\%)

\begin{tabular}{|c|c|c|c|c|}
\hline & 上 流 & 中 流 & 下 流 & 杂の他 \\
\hline $\begin{array}{l}\text { 職業威信による階層構造 } \\
(\text { エリ・・゙ルー) }\end{array}$ & 13 & 67 & 20 & - \\
\hline $\begin{array}{l}\text { 収入による階層構造 } \\
\text { (高額・額 } \text { 低額) }\end{array}$ & 3 & 27 & 70 & - \\
\hline $\begin{array}{l}\text { 自己判定に上る階稀構造 } \\
(\text { 上流・中流 }\end{array}$ & - & 56 & 42 & 2 \\
\hline
\end{tabular}




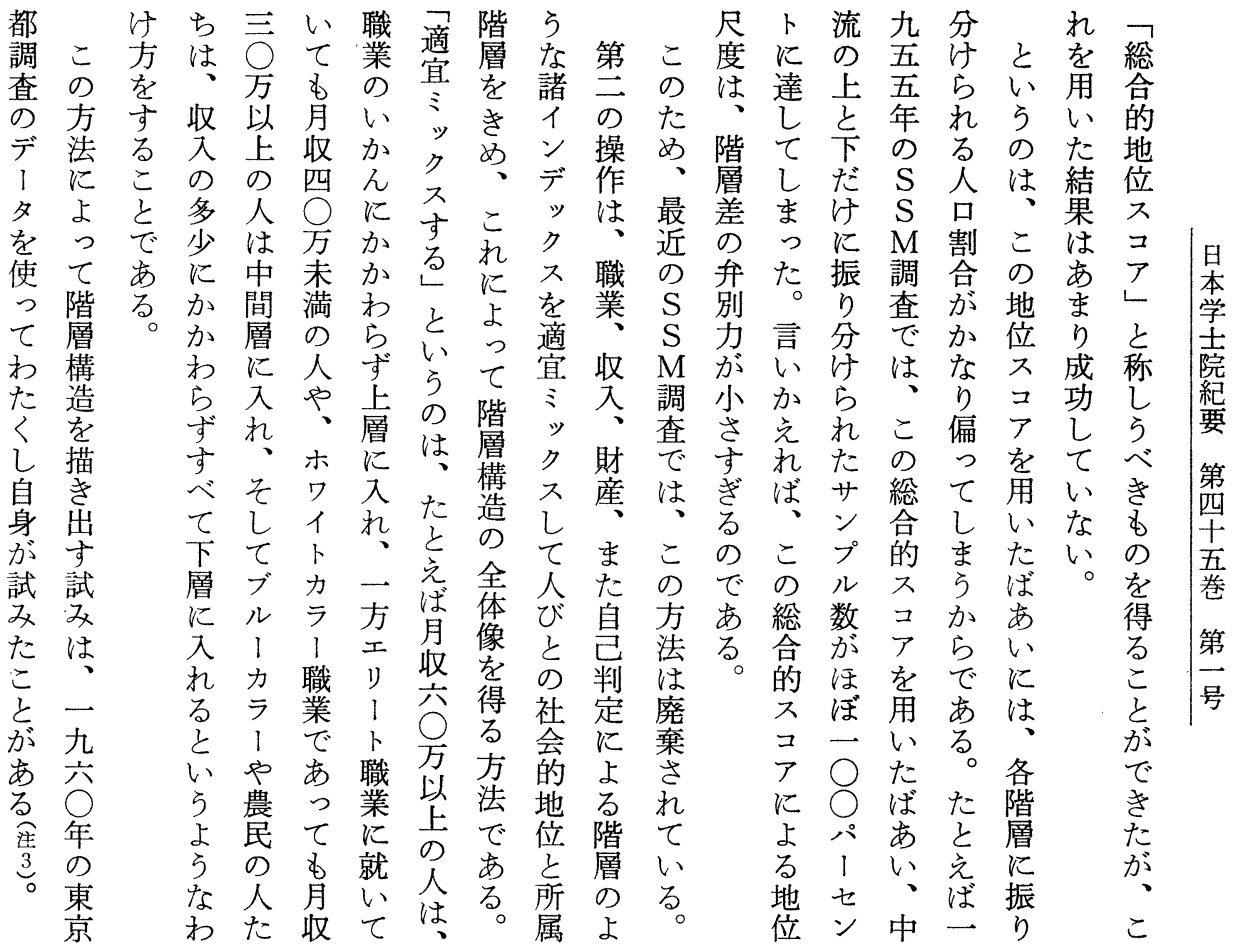

て 作近こくこずト|層こビ塔で京で

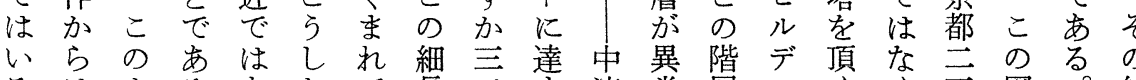

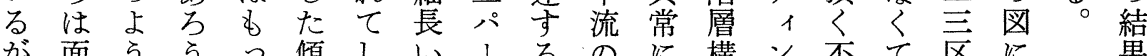

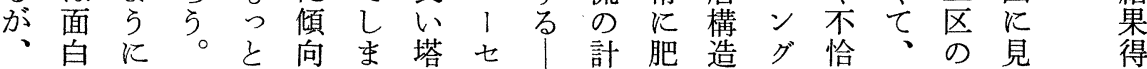
デい強はううのン階ら市ら

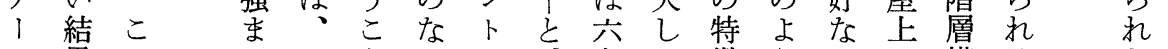

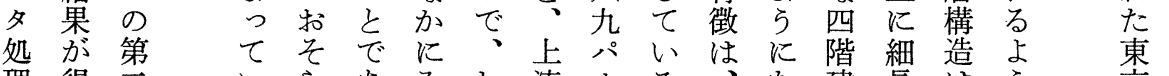

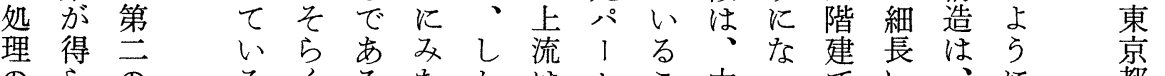

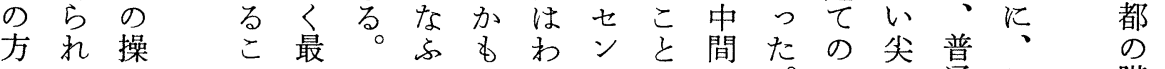
方れ操こ最。るもわとと間たの尖䍸こ 階

図 1：職業・収入・自己判定による階層構造の模型図 上流 $(3 \%)$

中流の上 中流の中 中流の下 下 流

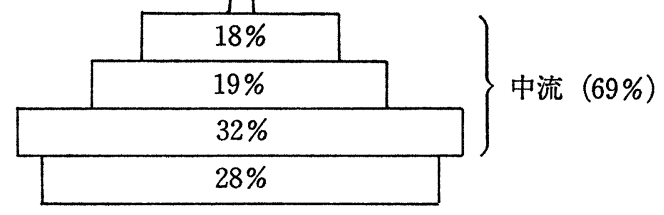

想 さ て 見 いて 取 る描図

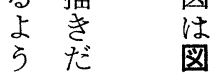
なさ 1 四 ピ机 ラ尔示 当 型東号 


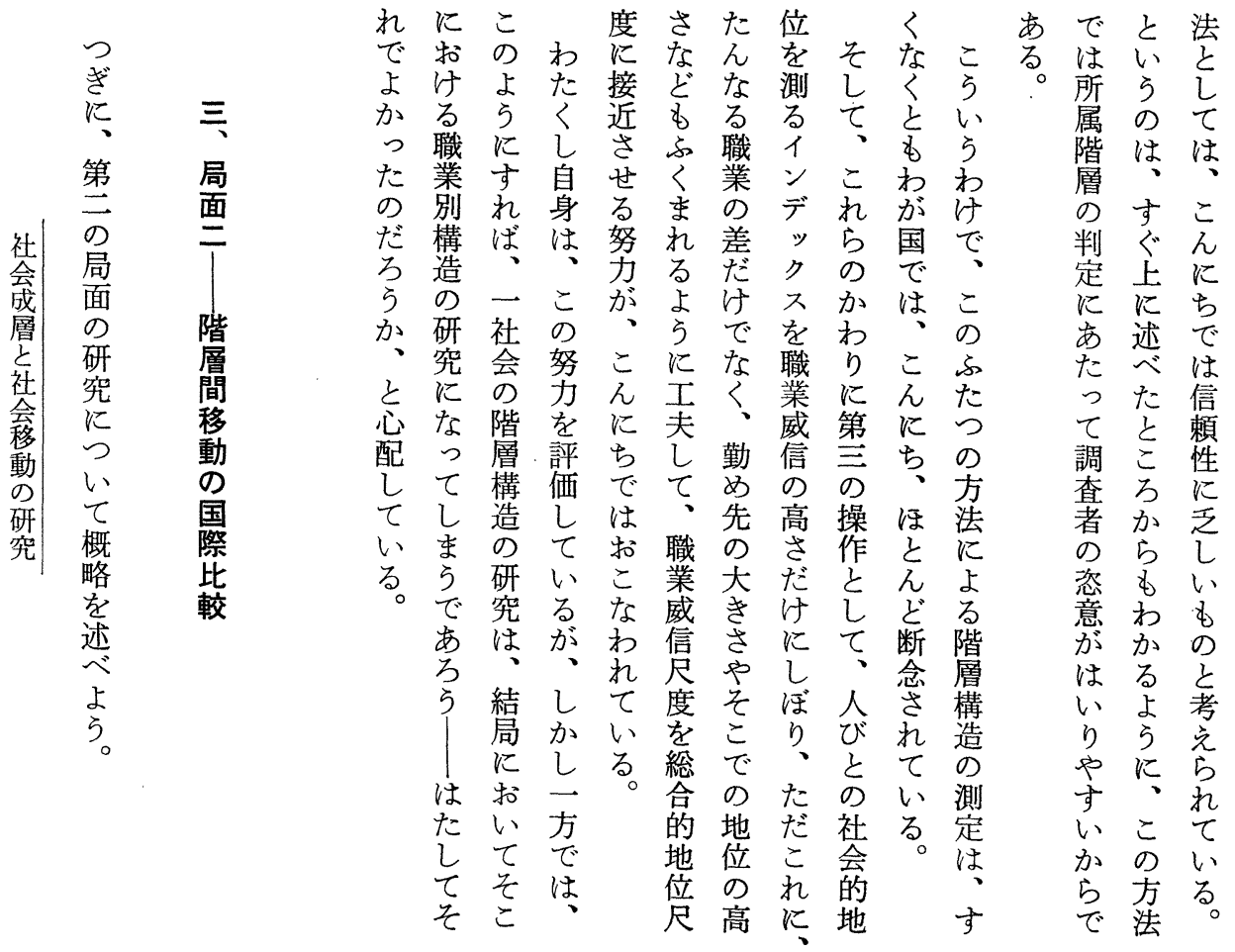

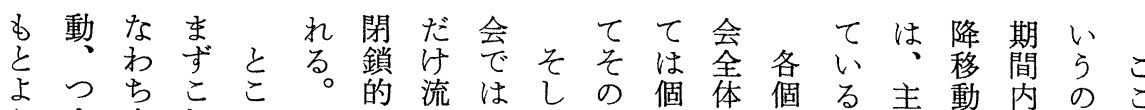

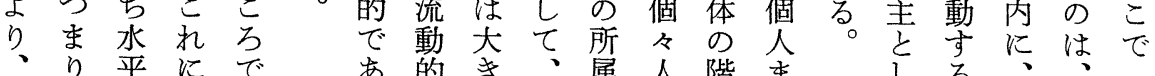

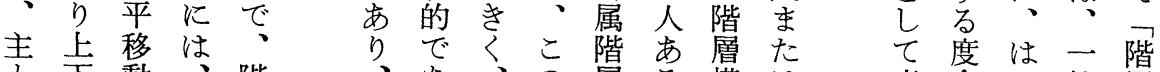

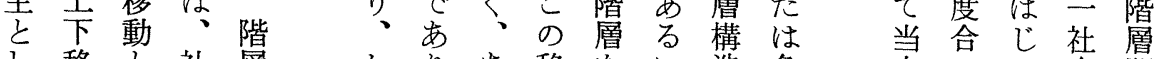

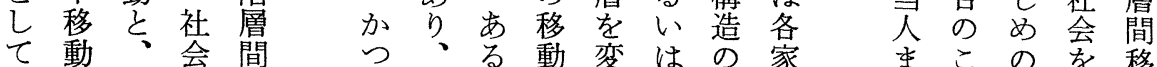

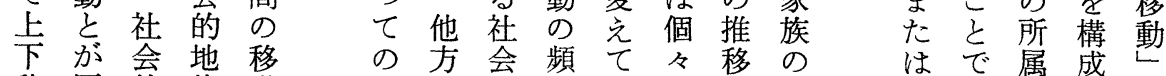

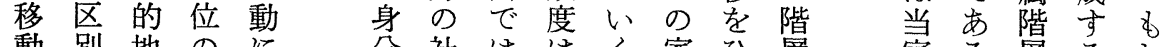
動別地のに分社は檖ひ層家る層るし をさ位上は制会小、プ族き間族。個く

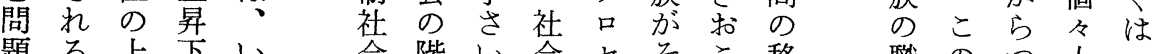
題る卡下い会階い会七そこ移職のつ人降

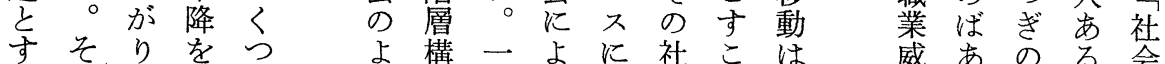

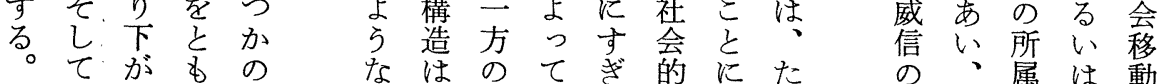

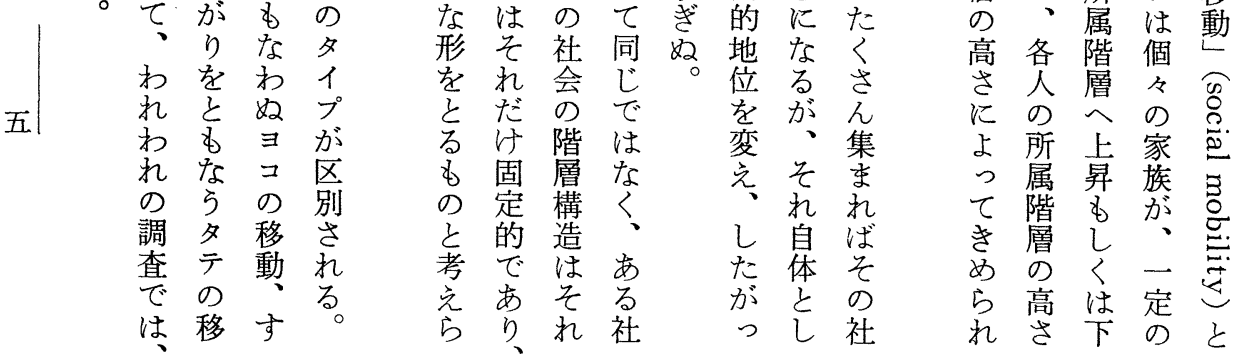




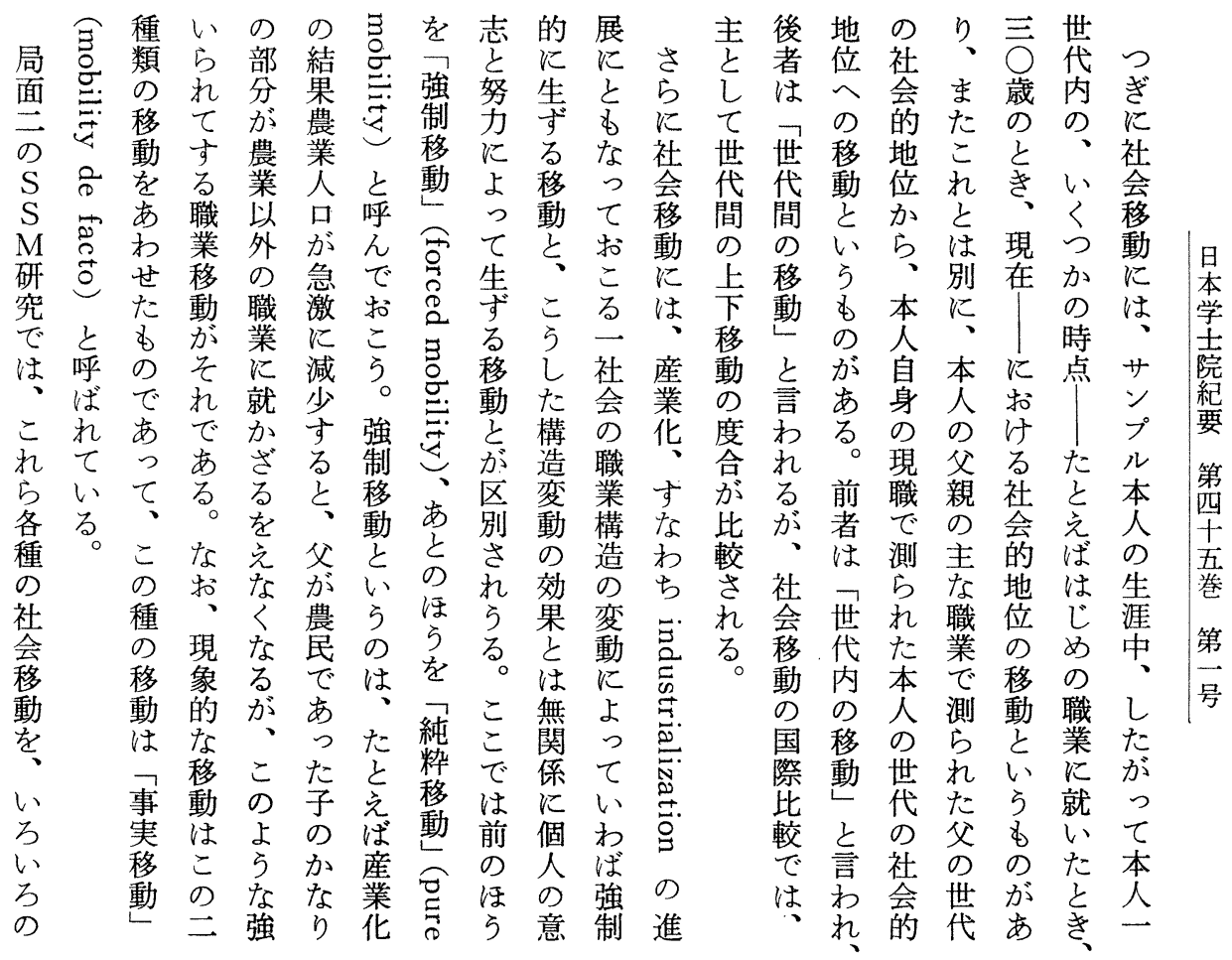

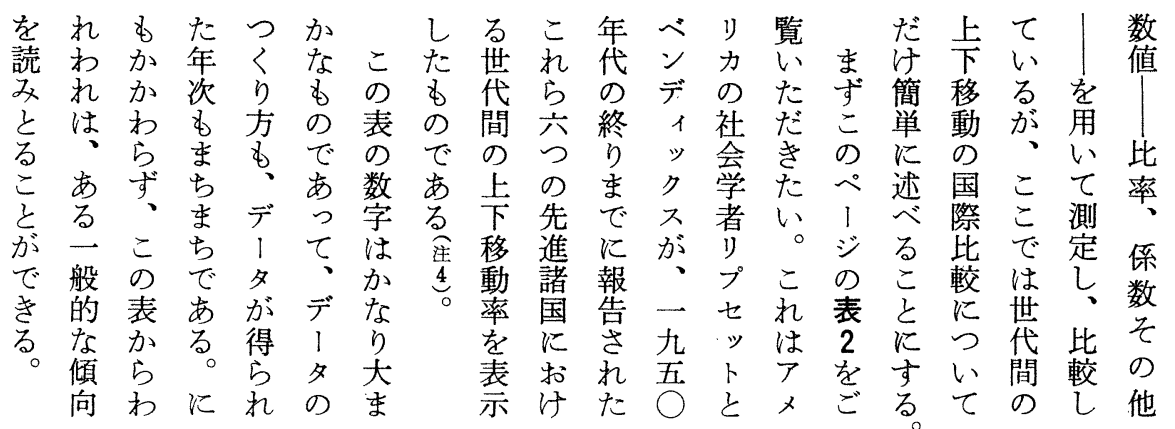

表 2：世代間社会移動率の国際比較（\%）

\begin{tabular}{|c|c|c|c|c|c|}
\hline 国 & \multicolumn{2}{|c|}{ 別 } & \multirow{2}{*}{ 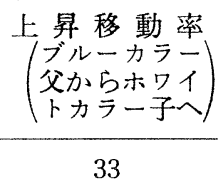 } & \multirow{2}{*}{ 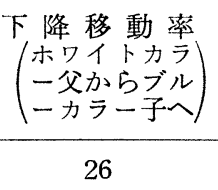 } & \multirow{2}{*}{ 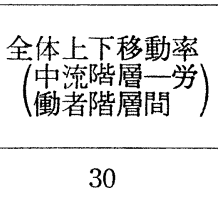 } \\
\hline > & × リ & 力 & & & \\
\hline 西 & & 独 & 29 & 32 & 31 \\
\hline スウ & 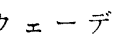 & & 31 & 24 & 29 \\
\hline 日 & & 本 & 36 & 22 & 27 \\
\hline 7 & ラ ン & ス & 39 & 20 & 27 \\
\hline x & 1 & x & 45 & 13 & 23 \\
\hline
\end{tabular}



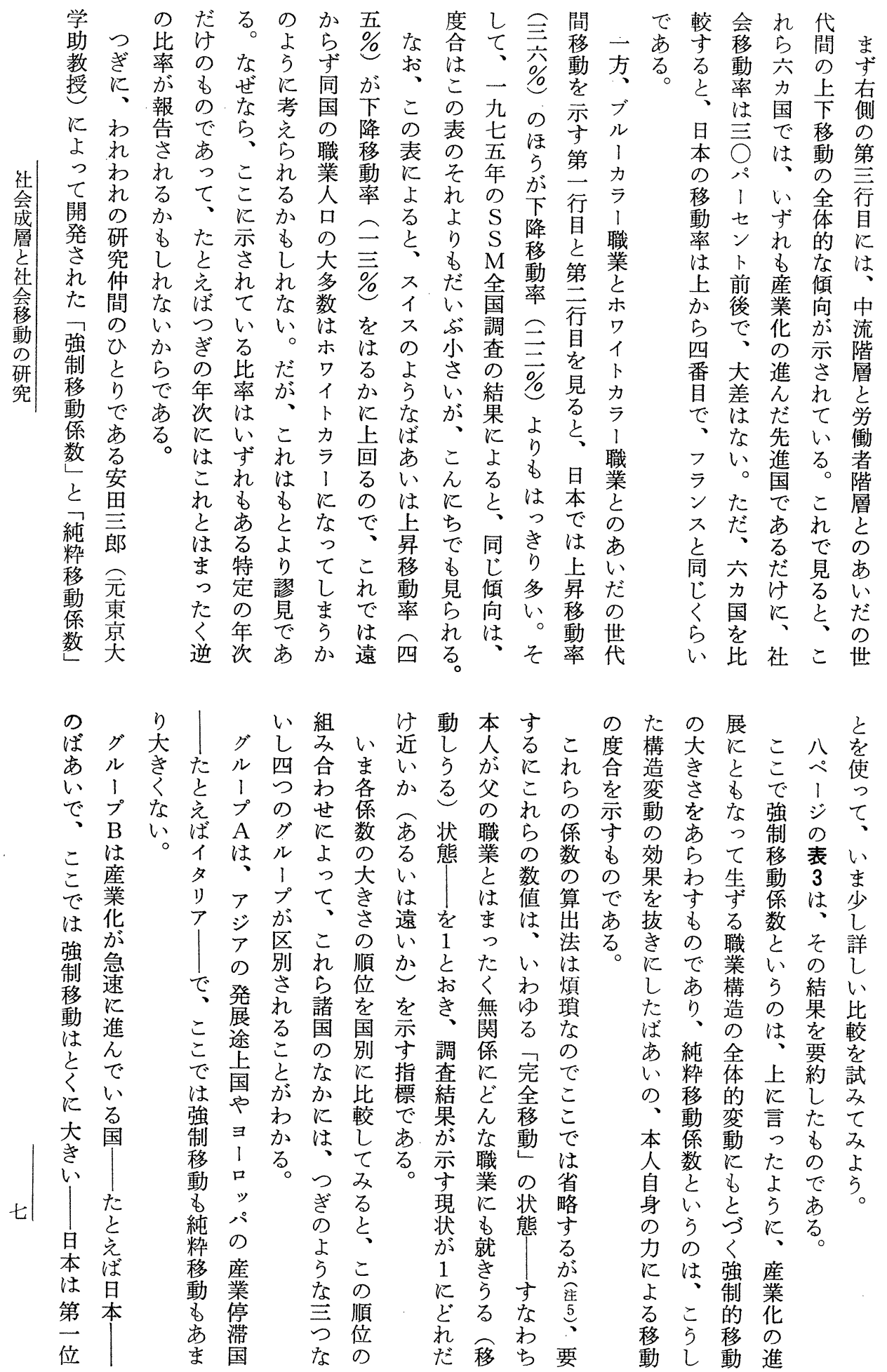


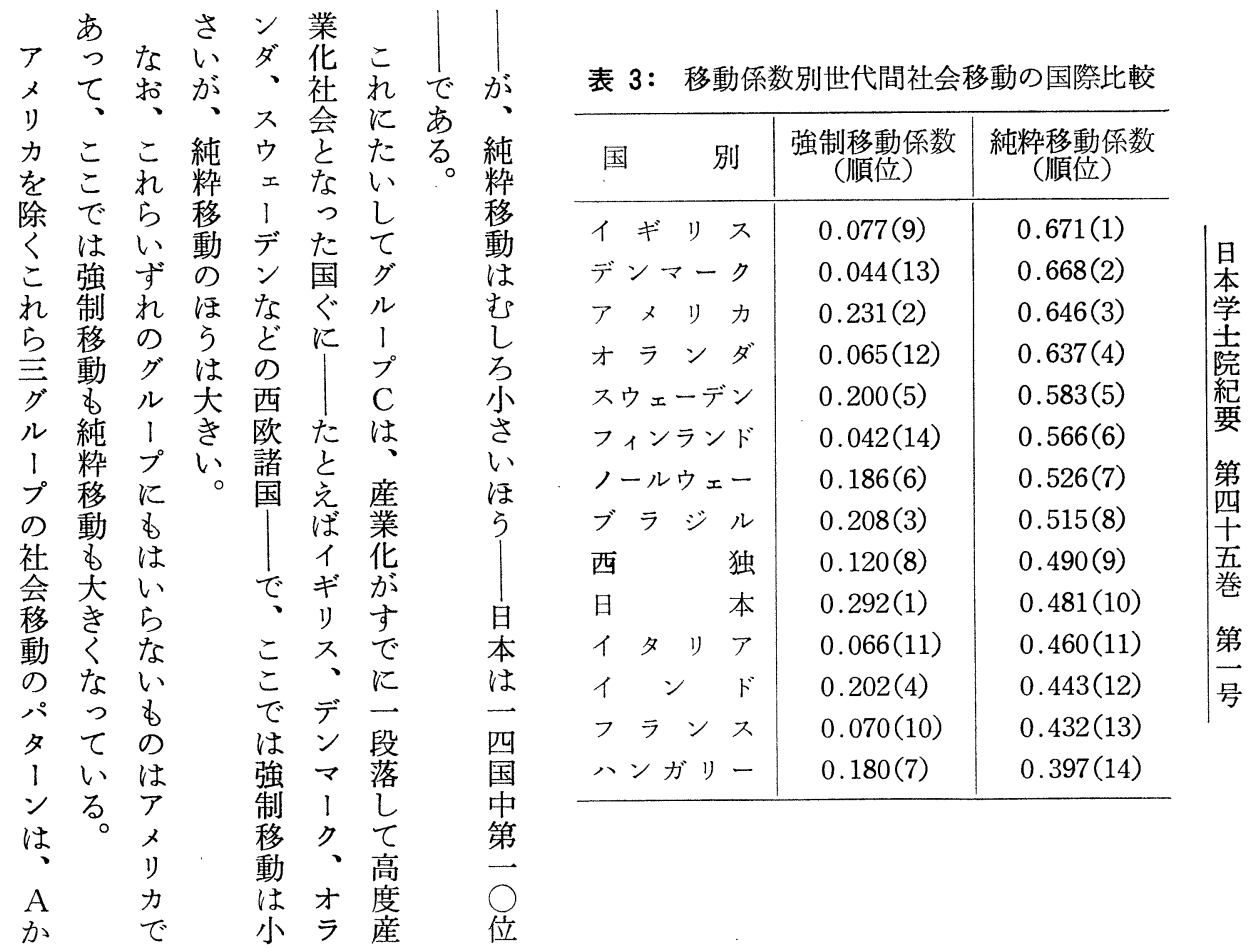

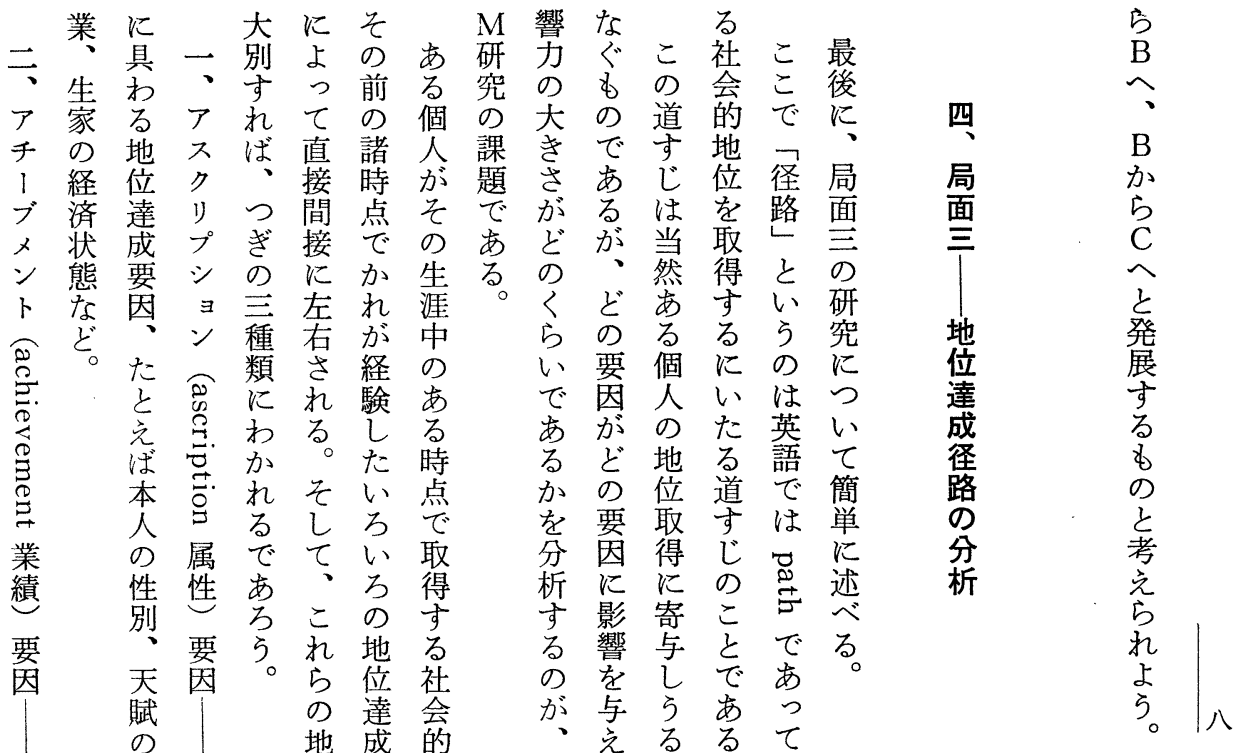



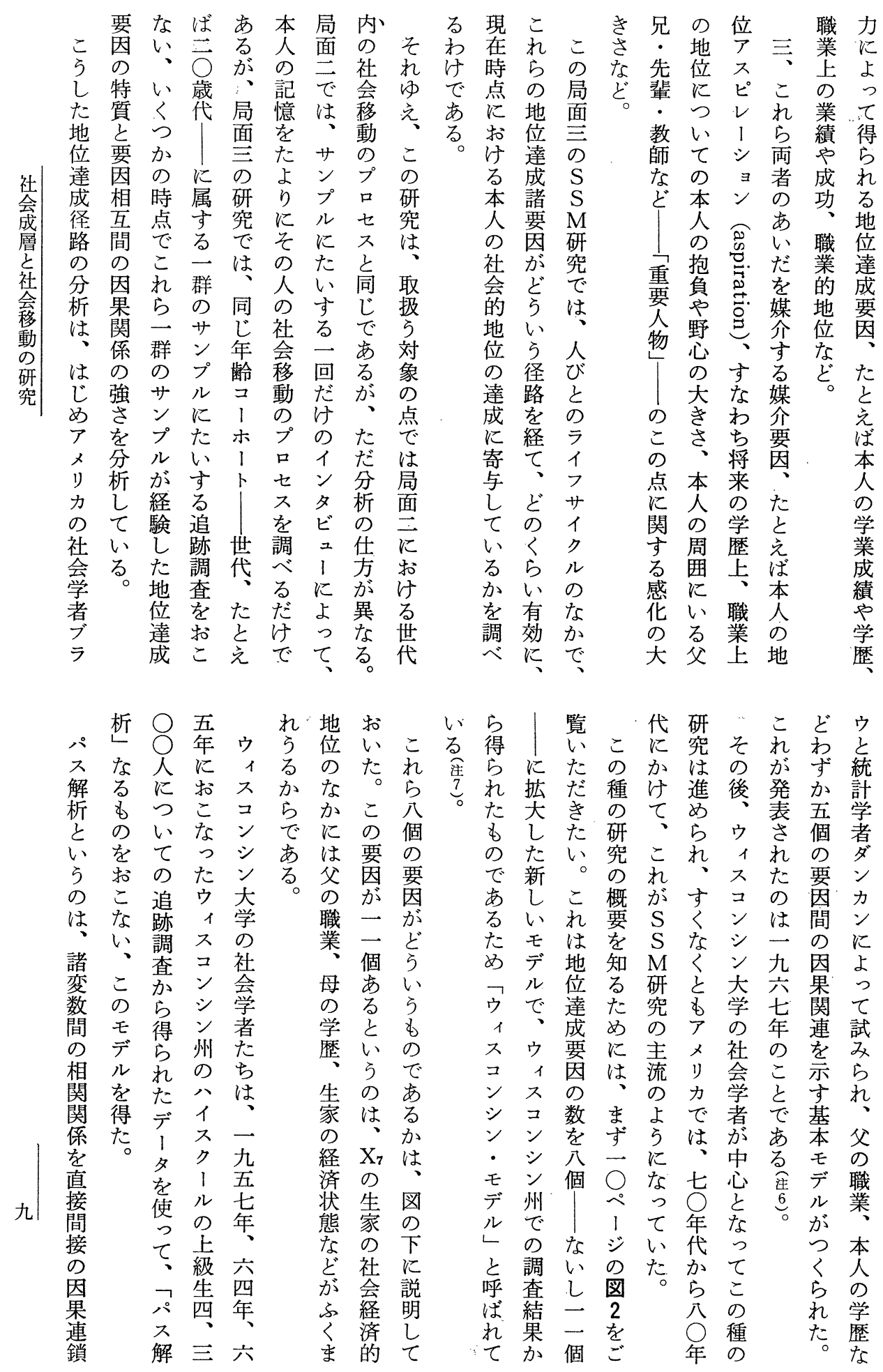


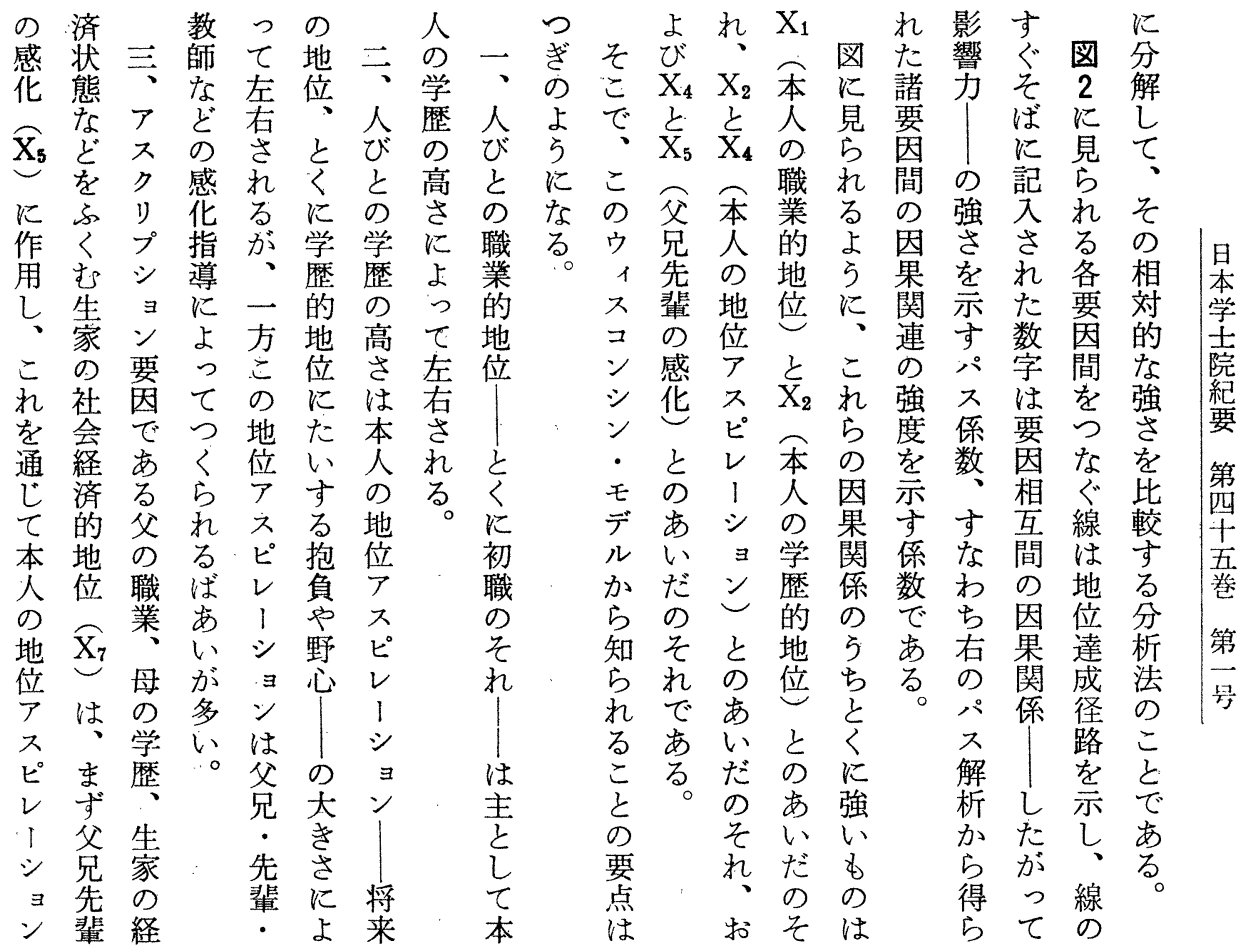

図 2：ウィスコンシン・モデルにおける地位達成径路とパス係数

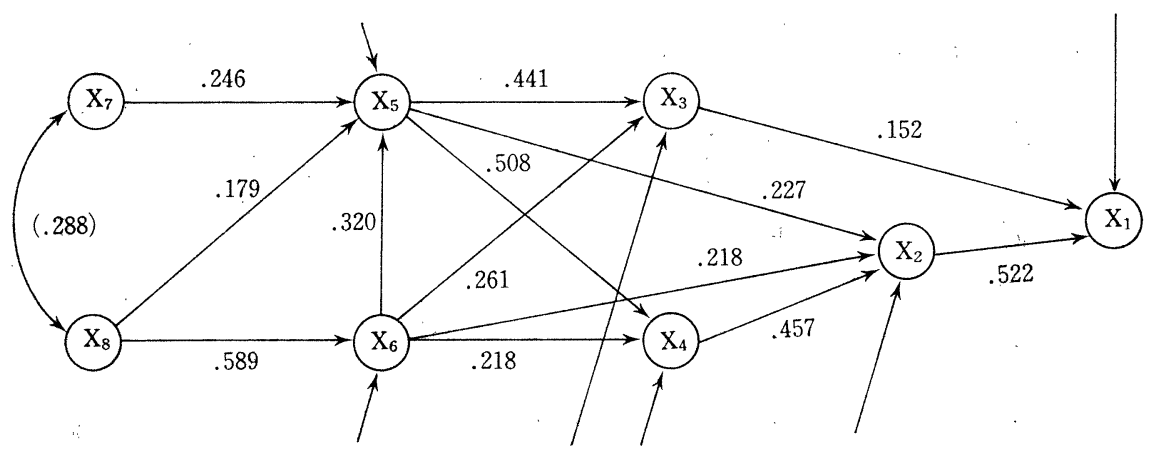

$\mathrm{X}_{1}$ ： 本人の職業的地位

$\mathrm{X}_{2}$ : 本人の学歴的地位

$\mathrm{X}_{3}$ ：本人の地位 (職業) アスピレーション

$\mathrm{X}_{4}$ ：本人の地位 (学歴) アスピレーション

$\mathrm{X}_{5}$ : 父兄先輩の感化

$\mathrm{X}_{6}$ : 本人の学業成績

$\mathrm{X}_{7}$ :" 生家の社会経済的地位

$\mathrm{X}_{8}$ : 本人の才能

(注): $\mathrm{X}_{7}$ には父の職業, 父の学歴, 母の学厢,

生家の経済状態などがふくるれる。 


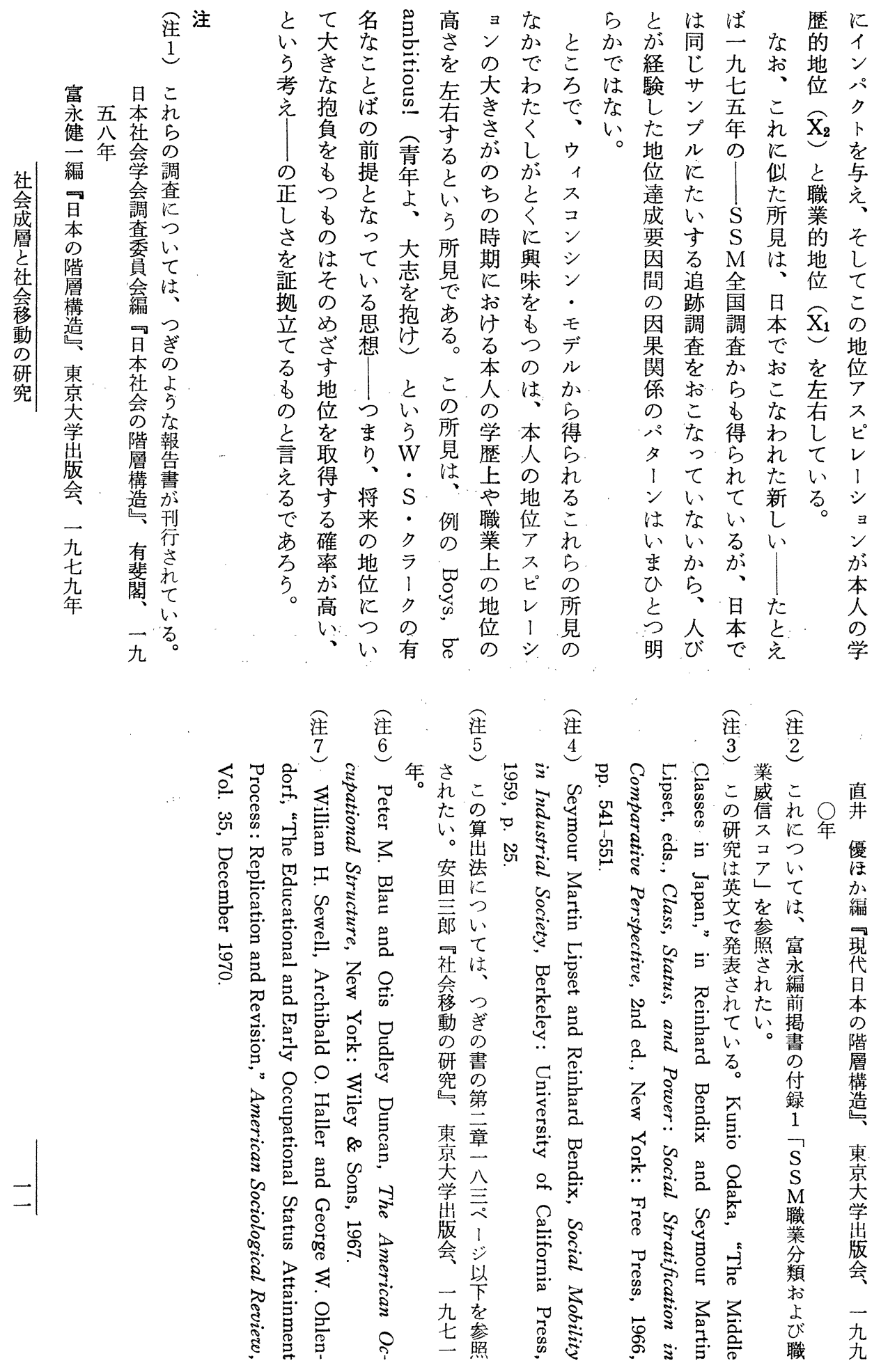




\section{A Brief Review of Studies in Social Stratification and Social Mobility}

Kunio Odaka, M. J. A.

1. Introduction

- International Sociological Association's project for comparative studies in social stratification and social mobility

2. Phase I: Problems of measuring a system of social stratification

- Occupation, education, income and property as indices to measuring one's social status

- Attempts to develop a synthetic scale of measuring one's social status

3. Phase II: International comparisons of inter-generational social mobility

- Intra-generational mobility and inter-generational mobility

- Forced mobility, pure mobility and mobility de facto

4. Phase III: Quantitative analyses of individuals' status attainment processes

- Longitudinal surveys of each age cohort of respondents

- Analyses of causal nexuses among the factors contributing to one's status attainment 